\title{
A Case Study on Corporate Social Responsibility Initiatives with Special Reference to Hindustan Unilever Limited
}

\section{* Mrs. Thara S.Shetty **Mr. Shreenidhi B.S.}

\section{Abstract}

Corporate Social Responsibility (CSR) is a concept with many definitions and practices. The way it is understood and implemented differs greatly for each company and country. Moreover, CSR is a very broad concept that addresses many and various topics such as human rights, corporate governance, health and safety, environmental effects, working conditions and contribution to economic development. Whatever the definition is, the purpose of CSR is to drive change towards sustainability. Corporate social responsibility (CSR) is now seen as an integral part of corporate strategy. The main purpose of the study is to analyze the corporate social responsibility (CSR) activities carried out by Hindustan Unilever Limited (HUL). An empirical and analytical study has been undertaken whereby the corporate official websites of the companies were analyzed. The most preferred CSR activities were observed to be women empowerment, self-employment, health hygiene and environment. The challenge for the companies is to determine a strong and innovative CSR strategy which should deliver high performance in ethical, environmental and social areas and meet all the stakeholders'objectives.

Key words: Corporate Social Responsibility, HUL, CSR activities

\section{Introduction}

Corporate Social Responsibility is also referred to as corporate conscience, corporate citizenship, sustainable responsible business

* Assistant Professor, Department of PG Studies in Commerce Besant Evening College, Mangalore.

** Assistant Professor, Department of PG Studies in Commerce Besant Evening College, Mangalore. 
or simply as responsible business. CSR is nothing but a selfregulatory mechanism adopted by corporates to ensure that all its business activities are according to law, follow ethical standards and international norms. CSR is not about environment conservation or about having a recycling policy. It is a procedure where corporates learn to respect legislative laws, moral values, people, communities and the natural environment. It is also to assess and ensure that their day to day operations have a positive impact on communities, cultures, societies and the environments in which they operate. According to CSR Asia, "CSR is a company's commitment to operating in an economically, socially and environmentally sustainable manner whilst balancing the interest of diverse stakeholders" World Business Council for Sustainable Development defines CSR as "The continuing commitment by business to behave ethically and contribute to economic development while improving the quality of life of the workforce and their families as well as the local community and society at large" World Bank Group states that "CSR is the commitment of business to contribute to sustainable economic development by working with employees, their families, the local community and society at large, to improve their lives in ways that are good for business and for development.

The benefits of CSR are many fold and the prominent ones are:

Corporate social responsibility (CSR) is a self-regulating business model that helps a company be socially accountable — to itself, its stakeholders, and the public. By practicing corporate social responsibility, also called corporate citizenship, companies can be conscious of the kind of impact they are having on all aspects of society including economic, social, and environmental. The society grants the business, its right to exist. So it is the duty of the business to respond to needs of the society constructively. As important as CSR is for the community, it is equally valuable for a company. CSR activities can help forge a stronger bond between employee and corporation; they can boost morale and can help both employees and employers feel more connected with the world around them. The term "Corporate Social Responsibility" came into common use in the late 
1960 s and early 1970 s after many multinational corporations formed the term stakeholder, meaning those on whom an organization's activities have an impact. Hindustan Unilever Limited (HUL) is India's largest Fast Moving Consumer Goods Company with a heritage of over 80 years in India and touches the lives of two out of three Indians. HUL works to create a better future every day and helps people feel good, look good and get more out of life with brands and services that are good for them and good for others.

\section{Definition of Corporate Social Responsibility}

Corporate Social Responsibility is a form of corporate selfregulation integrated into a business model. CSR policy functions as a built-in, self-regulating mechanism whereby a business monitors and ensures its active compliance with the spirit of the law, ethical standards, and international norms. CSR is a process with the aim to embrace responsibility for the company's actions and encourage a positive impact through its activities on the environment, consumers, employees, communities, stakeholders and all other members of the public sphere who may also be considered as stakeholders.

"Corporate Social Responsibility is the continuing commitment by business to behave ethically and contribute to economic development while improving the quality of life of the workforce and their families as well as of the local community and society at large".

"Corporate Social Responsibility is achieving commercial success in ways that honour ethical values and respect people, communities, and the natural environment."

Advantages:

- Stronger financial performance and profitability through efficient operations.

- Improved relations with the investment community and better access to capital

- Enhanced employee relations that yield better results respecting recruitment, motivation,

- Retention, learning and innovation, and productivity

- Stronger relationships with communities and enhanced 


\section{licence to operate}

- Improved reputation and branding

\section{Definition of Sustainability}

Corporate social responsibility (CSR) is a business approach that contributes to sustainable development by delivering economic, social and environmental benefits for all stakeholders.

Most widely cited definition of sustainable development is "Development that meets the needs of the present without compromising the ability of future generations to meet their own needs."

According to Webster, sustainability means:

- Able to be used without being completely used up or destroyed

- Involving methods that do not completely use up or destroy natural resources

As it relates to corporate social responsibility, sustainability means managing a business using sustainable methods:

- Methods that will not deplete, destroy, or completely use up natural resources

- Methods that can persist over long periods of time

- Methods that are able to last perpetually

\section{Literature Review}

In a study made by Caroll (1998) on top 500 largest Indian companies found that around 49 percent companies were reporting on CSR. Most of the companies report on donations, renovating schools in villages, mid day meals etc. well defined expenditure on CSR has been shown by very few companies. The study also revealed that only in 25 percent companies CSR activities were for employees and the rest were focusing on vicinity and society at large. Many companies are making only token gestures towards CSR in tangential ways such as donations to charitable trusts or NGOs, sponsorship of events, etc. believing that charity and philanthropy equals to CSR.

Arora and Puranik (2004) reviewed contemporary CSR trends in 
India concluding that the corporate sector in India. He concluded that the corporate sector in India has benefitted immensely from liberation and privatization process, its transition from philanthropic mindsets to CSR has been lagging behind its impressive financial growth.

Ramana Kumar, M (2013) in his study on CSR (Analysis of select Indian Private and Public sector companies) tried to analyse the CSR activities carried out by Indian Private (Reliance Industries Ltd.) and public sector companies (ONGC) and also study the Indian government policies and programmes of CSR. The study revealed that though the Indian public and private firms are making efforts in the CSR areas, still there is a requirement of more emphasis on CSR. The study found that there is a significant difference in the CSR practices of RIL and ONGC as the CSR budget of ONGC is more than RIL during the year 2009-10, 2010-11, and 2011-12 and average CSR score of ONGC is more than that of RIL during 2009 to 2013.

\section{Objectives}

The study is intended to achieve the following objectives:

- To know the inclusions of CSR activities under Companies Act 2013.

- To study the purpose and types of corporate social responsibility (CSR) activities carried out by HUL.

\section{Methodology}

The study is based on the data collected from the Annual Reports of Hindustan Uni Lever Limited (HUL). The study adopts descriptive and analytical research design.

\section{CSR activities as per Sec-135(Schedule, VII) of Companies Act-} 2013

According to the section 135, Schedule VII of Companies Act-2013 initiatives of CSR are:

- Eradicating extreme hunger and poverty

- Promotion of education

- Promoting gender equality and empowering women 
- Reducing child mortality and improving maternal health

- Combating human immunodeficiency virus, acquired immune deficiency syndrome, malaria and other diseases

- Ensuring environmental sustainability

- Employment enhancing vocational skills

- Social business projects

- Contribution to the Prime Minister's National Relief Fund or any other fund set up by the Central Government or the State Governments for socio- economic development and relief and funds for the welfare of the Scheduled Castes, the Scheduled Tribes, other backward classes, minorities and women. 10 Other activity not mentioned above Source: Sec135-(Schedule VII) Companies Act 2013.

\section{Legal Provisions on applicability of CSR}

Section 135(1) of the Companies Act, 2013 provides for the trigger point for the applicability of CSR Provisions and constitution of CSR Committee. The constitution of CSR committee is mandatory in company having:

- Net Worth of Rs. 500 Crore

- Turnover of Rs. 1000 Crore

- NetProfit of Rs. 5 Crore during any financial year.

\section{CSR Expenditure:}

As per Section 135(5), at least 2 percent of the average net profits of the company during three immediately preceding financial years must be spent against CSR as provided in CSR Policy."

\section{History/Background of HUL}

HUL is an Indian consumer goods company based in Mumbai, Maharashtra. It is owned by Anglo-Dutch Company Unilever which owns a 67 percent controlling share in HUL. HUL's products include food items, beverages, cleaning agents and personal care products. HUL was established in 1933 as Lever Brothers India Limited and, in 
1956, to be came to known as Hindustan Lever Limited, as a result of a merger between Lever Brothers, Hindustan Vanaspati Mfg. Co. Ltd. and United Traders Ltd. It is headquartered in Mumbai, India and employs over 16,500 employees, also indirectly helping to facilitate the employment of over 65,000 people. The company was renamed in June 2007 as "Hindustan Unilever Limited". HUL's distribution covers over 2 million retail outlets across India directly and its products are available in over 6.4 million outlets in the country. As per Nielsen market research data, two out of three Indians use HUL products. HUL is India's largest Fast Moving Consumer Goods (FMCG) Company with a heritage of over 80 years in India. With over 35 brands spanning 20 distinct categories such as soaps, detergents, shampoos, skin care, toothpastes, deodorants, cosmetics, tea, coffee, packaged foods, ice cream, and water purifiers, HUL is a part of the everyday life of millions of consumers across India. Its portfolio includes leading household brands such as Lux, Lifebuoy, Surf Excel, Rin, Wheel, Fair \& Lovely, Pond's, Vaseline, Lakmé, Dove, Clinic Plus, Sunsilk, Pepsodent, Closeup, Axe, Brooke Bond, Bru, Knorr, Kissan, Kwality Wall's and Pureit.

\section{Vision}

The four pillars of HUL's vision sets out the long-term direction for the company - where it wants to go and how it is going to get there:

- Work to create a better future every day.

- Help people feel good, look good and get more out of life with brands and services that are good for them and good for others.

- Inspire people to take small everyday actions that can add up to a big difference for the world.

- Develop new ways of doing business with the aim of doubling the size of company while reducing environmental impact. Believing in the power of brands to improve the quality of people's lives and in doing the right things. 
Table No. 1: CSR Financial Details (INR Cr)

\begin{tabular}{|l|c|c|c|}
\hline \multicolumn{1}{|c|}{ Year } & $\mathbf{2 0 1 5 - 1 6}$ & $\mathbf{2 0 1 6 - 1 7}$ & $\mathbf{2 0 1 7 - 1 8}$ \\
\hline Actual CSR & 92.12 & 103.88 & 116.09 \\
\hline Prescribed CSR & 91.94 & 101.71 & 112.20 \\
\hline
\end{tabular}

Source: Company Report

It can be observed in the Table that during 2015-2018 the company has spent more than the amount prescribed on CSR activities.

\section{Mission}

HUL's mission is to add vitality to life. HUL meets every day needs for nutrition, hygiene, and personal cares with brands that help people feel good, look good and get more out of life.

Industry \& Products HUL is India's largest FMCG Company, touching the lives of two out of three Indians with over 20 distinct categories in home $\&$ personal care products and food $\&$ beverages. The Indian FMCG sector is the fourth largest in the economy and has a market size of US\$13.1 billion. Well-established distribution networks, as well as intense competition between the organized and unorganized segments are the characteristics of this sector. FMCG in India has a strong and competitive MNC presence across the entire value chain.

Hindustan Unilever Products are divided into four categories: (1) Personal Care Products; (2) Home care products; (3) Food and Drinks; and (4) Water Purifiers. According to the study conducted by AC Nielsen, MNCs own top 160 brands. Fifteen Indian Companies own 62 of these brands and out of 62, HUL owns 27 brands. Aglimpse of some of the products of HUL is given in the following picture:

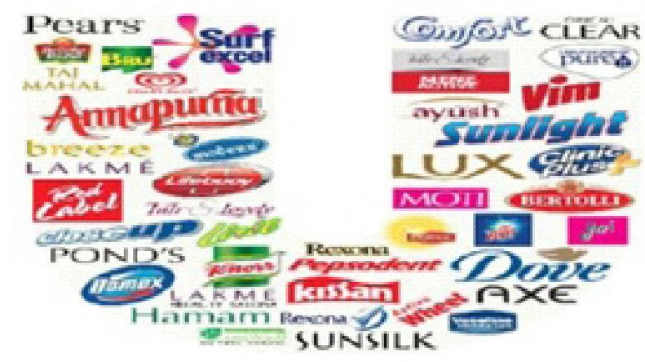




\section{CSR Initiatives by HUL}

\section{Project Shakti}

Project Budget in 2017-18 is Rs. 41.77 crores. Project Shakthi started in 2001 with 17 women in two states. Project Shakti is an initiative to financially empower rural women and create livelihood opportunities for them. Through this project, the Company endeavors to enhance livelihoods of rural women. Around 70 percent of Shakti Ammas are working in low Human Development Index (HDI < 0.51) districts. HUL contacts and appoints rural women as Shakti Entrepreneurs (SE), commonly referred as 'Shakti Ammas'. SE is educated and trained by the rural promoter about the Company products and their utility in day to day life in maintaining health and hygiene. After being trained about the products she receives stocks from the company's rural distributor at a discount below the price at which the products are sold in the normal course. The Shakti Entrepreneur then sells these goods both directly to consumers (through home to home selling) and to retailers in the village. The Company has trained thousands of Shakti Ammas across the villages in a bid to develop an entrepreneurial mindset and make them financially independent and more empowered. Project Shakthi has nearly 80,000 entrepreneurs across 18 states.

\section{Swachh Aadat Swachh Bharat}

The project budget for the year $2017-18$ is Rs. 30.48 crores. The project is in line with Government of India's Swachh Bharat Abhiyan to promote good health and hygiene practices and aims to achieve the Swachh Bharat goals by 2019. The goal is to popularise the adoption of 3 clean habits: (i) wash hands before meals and after defecation, (ii) adopt safe drinking water practices and (iii) stop open defecation. Build partnerships to identify, advocate, and create awareness of existing solutions and to create new ones in the areas of Waste Management and Sanitation. As a part of Swacha Adat and Swachh Bharat, Swachhta Doot is a volunteering programme that enables any person to become a change agent in his community. It is a mobile led WASH communication model to help create awareness on the three clean habits in communities. Till date the company has reached 7.5 
million people through this programme. In 2017 alone 4.5 million have been reached. The community hygine centre-Suvidha Centre- is another important project by the company to contribute to SASB. Suvidha is the first of its kind urban water, Hygine and Sanitation. Community centre in Azadnagar, Ghatkopar one of the largest slums in Mumbai. The community centre provides drinking water, sanitation, hand washing, shower facilities and laundry services at an affordable cost. The Centre uses circular economy principles to reduce the water usage. The centre was built in partnership with the Muncipal Corporation of Greater Mumbai and Pratha Samajik Sanstha, a community based organisation.

\section{Hand Washing Behaviour Change Programme}

More than 600,000 children in India do not reach the age of five due to infections like diarrhea and pneumonia. Independent research has shown that washing hands with soap at five critical times in a day can reduce the incidence of these infections significantly. Therefore inculcating behavior change amongst people is important. The experience shows that children are in the best position to bring in this change among their respective families. The Company conducts hand washing awareness programmes in anganwadis (preschool centre) and schools. Under the initiatives such as 'Help A Child Reach 5' and School Contact Programs in Bihar in partnership with Children Investment Fund Foundation (CIFF) and the Government of Bihar, the Company promotes hand washing behavior change among children in Bihar.

The 'Help a Child Reach 5', hand washing campaign started in 2013 in Thesgora in Madhya Pradesh.

This initiative will help reduce the incidence of life-threatening diseases like diarrhea and pneumonia which claim lives of over 600,000 children in India. The initiative aims to reach 163 million people by 2020 .

\section{Domex Toilet Academy (DTA)}

Project location- Andhra Pradesh - Project budget during 2017-18 has been INR 2.33 crores. It is a unique market based entrepreneurial 
model launched by the company in 2014. DTA programme trains entrepreneurs and masons to help build and maintain toilets, provides access to micro-financing and creates demand for toilets in low income households.

The World Health Organisation and United Nations Children's Education Fund (UNICEF) estimate that there are more than 620 million people practicing open defecation due to lack of access to proper sanitation and 60 percent of all open defecation in the world are in India. DTA and eKutir Rural Management Services Private Limited, a social enterprise identifies and trains local microentrepreneurs who help execute the project in their local communities by supplying and building toilets. DTA provides the seed capital to these entrepreneurs through eKutir to start up their activity, and also helps with initial operational costs for the execution of the project. The objective is to reduce the incidence of open defecation and improve proper sanitation thereby promoting preventive healthcare. DTA works with local self-help groups who educate people on the importance of proper sanitation and provide them access to micro-loans through micro-finance institutions to buy the toilets from the local micro-entrepreneur appointed by DTA.

Half of the population in India does not have access to proper sanitation facilities. In many cases people do not use toilets for defecation. Therefore, it is important to create awareness about behavior change on improved sanitation. In the long run and by 2020 , the company has planned to help large number of people to improve their hygiene habits in India.

\section{Safe Drinking Water}

The lack of safe drinking water is a major public health issue, particularly in developing countries where majority of diseases are waterborne. Pureit in-home water purifier provides water 'as safe as boiled water', without the need for electricity or running water. Pureit partners with NGOs across the country to make safe drinking water accessible to people. HUL aims to make safe drinking water available and affordable to people from economically weaker 
sections of society in partnership with microfinance and NGO partners in India.

\section{FAL Foundation}

The Foundation identifies academically exceptional girls from financially challenged backgrounds and offers scholarships to the candidates. To maintain integrity and fairness the selection is done by a panel of eminent personalities from diverse fields. The Foundation is around a decade old. It is a long term endeavor of the Company to help exceptionally bright girls with scholarships granted through FAL Foundation.

\section{Sustainable Sourcing}

An important part of our raw materials come from farms and decisions relating to such procurement can have profound implications on climate change and farmers' livelihoods. In 2012, the Company entered into a public-private partnership with the Maharashtra Government for sustainable sourcing of tomatoes locally. HUL is committed to sourcing all our agricultural raw materials sustainably by 2020 .

\section{Water Conservation Projects}

Project Budget for 2017-18 is Rs. 30.02 crores. It is a "Water for Public Good" programme with specific focus on empowering local community institutions to govern water resources and enhancing farm based livelihoods through adoption of judicion water practices HUL has projects across nearly 2400 villages in 57 districts with 20 partners in India. Estimates tell that by 2030 , the supply of water in India will be half its demand. To understand and partake in meeting this challenge, HUL set up the Hindustan Unilever Foundation in 2010. It is a Section 8 not-for-profit Company that anchors various community development initiatives of Hindustan Unilever Limited. Hindustan Unilever Foundation supports national priorities for socio-economic development, through its Water for Public Good programme. Each of our projects also complies with the requirements of the National Voluntary Guidelines and the Companies Act, 2013. By 2020, HUL's partnerships and collective 
actions would make available a cumulative water potential of 500 billion liters across India.

\section{Relief Funds}

HUL has always been at the forefront in responding to its call for national duty and has contributed generous amounts for upliftment of community hit by natural disasters. It has done this through contribution to Government Relief Funds. This is driven by occurrence of event.

\section{Prabhat}

Project Budget for 2017-18 is 5.44 crores. 'Prabhat' (Dawn) is a program which focuses on communities around our factories. The areas of intervention are Health \& Hygiene, raising livelihoods and conserving water. The Water Conservation initiative is led by Hindustan Unilever Foundation, a wholly owned subsidiary of HUL which looks at improving the water security in selected regions. The Livelihood programme aims to empower today's youth by providing them with employable skills thereby enhancing their livelihoods. HUL is collaborating with NGOs to implement the project. The project aims to create a positive social impact in the lives of one million people. In 2017, this project surpassed the ambitious target of directly impacting on the lives of one million people. For its launch in 2013 December in 8 locations, Project Prabhat is now lives over 30 locations across the country and directly benefits over 1.7 million people. The key focus areas are enhancing livelihoods, Water conservation and Health and Hygiene Awareness.

Under Prabhat livelihood initiatives in partnership with Labour net, TARA, Mann Deshi Foundation over 30,000 people have been successfully certified and over 21,000 have already been linked to employment opportunities till December 2017.

\section{Happy Homes: Asha Daan and Ankur}

Asha Daan Project Budget for 2017-18 is Rs. 1.7 crores. Asha Daan: The initiative began in 1976, when HUL supported Mother Teresa and the Missionaries of Charity to set up Asha Daan, a home in Mumbai for abandoned, challenged children, the HIV-positive and 
the destitute. Asha Daan has been set up on a 72,500-square feet plot belonging to HUL, in the heart of Mumbai city. Since the inception of Asha Daan in 1976, HUL has been looking after the maintenance of the premises. At any point of time, HUL takes care of over 400 infants, destitute men and women and HIVpositive patients at Asha Daan.

Ankur: Project Budget for $2017-18$ is Rs. 0.28 crores. Ankur is a centre for special education for otherwise challenged children at the Doom Dooma in Assam. It was set up in 1993 by HUL's Plantations Division at Doom Dooma. Ankur provides educational, vocational and recreational activities to specially-abled children.

It is ongoing and long term charitable activity; to provide shelter to the underprivileged members of the society; these include abandoned, challenged children, the HIV positive and the destitute. While HUL funds the annual maintenance of the premises, the Missionaries of Charity look after the inmates.

\section{Sanjivani}

HUL runs a free mobile medical service camp -- Sanjivani -- near its Doom Dooma Factory in Assam. The aim is to provide free mobile medical facility in the interior villages of Assam. There are two mobile vans dedicated to the project, each vehicle has one male and one female doctor, two nurses, a medical attendant (helper) and a driver. The vans are equipped with basic kits such as diagnostic kit, blood pressure measuring unit, medicines and a mobile stretcher. In 2017 alone nearly 17,800 patients were treated through this programme.

It is ongoing and long term preventive healthcare activity. The Company's aspiration is to provide healthcare in far and remote areas where basic medical facility is not available through our mobile medical service camps and thereby help a large number of the population over a period of time.

\section{Rin Career Ready Academy}

The program aims to inspire, educate and equip the youth from modest backgrounds with skills in English training, Office Dressing 
and Interviewing. The program allows all the participants to take the course by simply giving a missed call. Deserving individuals shall be put up for a more intensive face to face three week course, designed to suit their needs.

Table No. 1: List of activities under CSR initiatives and Amount spent on different programme

\begin{tabular}{|c|c|c|c|c|c|c|c|}
\hline \multirow[t]{2}{*}{$\begin{array}{l}\text { Sr. } \\
\text { No }\end{array}$} & \multirow[t]{2}{*}{$\begin{array}{c}\text { CSR } \\
\text { Project } \\
\text { /activity } \\
\text { identified }\end{array}$} & \multirow{2}{*}{$\begin{array}{l}\text { Relevant } \\
\text { Section of } \\
\text { Schedule } \\
\text { VII in } \\
\text { which the } \\
\text { Project is } \\
\text { covered } \\
\text { (Note 1) }\end{array}$} & \multirow[t]{2}{*}{$\begin{array}{c}\text { Project/P } \\
\text { rogramm } \\
\text { er } \\
\text { Coverage }\end{array}$} & \multirow[t]{2}{*}{$\begin{array}{c}\text { Amount } \\
\text { outlay } \\
\text { (budget) } \\
\text { (Rs) Cr }\end{array}$} & \multicolumn{2}{|c|}{$\begin{array}{c}\text { Amount spent on } \\
\text { the project/ } \\
\text { programme } \\
\text { (Rs) } \mathrm{Cr}\end{array}$} & \multirow{2}{*}{\begin{tabular}{|c|} 
Cumulative \\
expenditure \\
upto 31 st \\
March \\
2016 \\
\end{tabular}} \\
\hline & & & & & $\begin{array}{c}\text { Diretor } \\
\text { Expend } \\
\text { iture }\end{array}$ & $\begin{array}{c}\text { Overhea } \\
\text { ds }\end{array}$ & \\
\hline 1 & $\begin{array}{l}\text { Project } \\
\text { Shakti }\end{array}$ & [ii] & $\begin{array}{l}\text { PAN } \\
\text { India }\end{array}$ & 4,342 & 4,342 & - & 4,342 \\
\hline 2 & $\begin{array}{l}\text { Swachh } \\
\text { Aadat } \\
\text { Swachh } \\
\text { Bharat }\end{array}$ & [I] & $\begin{array}{l}\text { PAN } \\
\text { India }\end{array}$ & 1847 & 1847 & - & 1847 \\
\hline 3 & \begin{tabular}{|c|} 
Water \\
Conservati \\
on Project
\end{tabular} & [iv] & $\begin{array}{l}\text { PAN } \\
\text { India }\end{array}$ & 2125 & 1773 & 352 & 2125 \\
\hline 4 & Asha Daan & [iii] & Mumbai & 172 & 172 & - & 172 \\
\hline 5 & $\begin{array}{l}\text { Project } \\
\text { Prabhat }\end{array}$ & {$[\mathrm{x}]$} & $\begin{array}{l}\text { PAN } \\
\text { India }\end{array}$ & 508 & 484 & 26 & 508 \\
\hline 6 & Sanjivini & {$[\mathrm{I}]$} & Assam & 70 & 70 & - & 70 \\
\hline 7 & Ankur & [iii] & Assam & 22 & 22 & - & 20 \\
\hline 8 & $\begin{array}{l}\text { Solidaridad } \\
\text { Sustainabil } \\
\text { ity (Teac } \\
\text { Procureme } \\
\text { nt) }\end{array}$ & [iv] & $\begin{array}{l}\text { PAN } \\
\text { India }\end{array}$ & 126 & 126 & - & 126 \\
\hline & TOTAL & & & 9,212 & 8,836 & 376 & 9212 \\
\hline
\end{tabular}

Source: Compiled from Different Sources 
Table No. 2: List of activities in which expenditure in above has been incurred up to 31st March 2018 (Rs. In Lakh)

\begin{tabular}{|c|c|c|c|c|c|c|c|}
\hline \multirow[t]{2}{*}{$\begin{array}{l}\text { Sr. } \\
\text { No }\end{array}$} & \multirow[t]{2}{*}{$\begin{array}{c}\text { CSR } \\
\text { Project } \\
\text { /activity } \\
\text { identified }\end{array}$} & \multirow{2}{*}{$\begin{array}{l}\text { Relevant } \\
\text { Section of } \\
\text { Schedule } \\
\text { VII in } \\
\text { which the } \\
\text { Project is } \\
\text { covered } \\
\text { (Note 1) }\end{array}$} & \multirow[t]{2}{*}{$\begin{array}{c}\text { Project/P } \\
\text { rogramm } \\
\text { er } \\
\text { Coverage }\end{array}$} & \multirow[t]{2}{*}{$\begin{array}{c}\text { Amount } \\
\text { outlay } \\
\text { (budget) } \\
\text { (Rs) Cr }\end{array}$} & \multicolumn{2}{|c|}{$\begin{array}{l}\text { Amount spent on } \\
\text { the project/ } \\
\text { programme } \\
\text { (Rs) } \mathrm{Cr}\end{array}$} & \multirow{2}{*}{\begin{tabular}{|c} 
Cumulative \\
expenditure \\
upto 31 st \\
March \\
2018 \\
\end{tabular}} \\
\hline & & & & & $\begin{array}{c}\text { Diretor } \\
\text { Expend } \\
\text { iture }\end{array}$ & $\begin{array}{c}\text { Overhea } \\
\text { ds }\end{array}$ & \\
\hline 1 & $\begin{array}{l}\text { Project } \\
\text { Shakti }\end{array}$ & [ii] & $\begin{array}{l}\text { PAN } \\
\text { India }\end{array}$ & 4.177 & 4.177 & 0 & 4,177 \\
\hline 2 & $\begin{array}{l}\text { Swachh } \\
\text { Aadat } \\
\text { Swachh } \\
\text { Bharat }\end{array}$ & [i] & $\begin{array}{l}\text { PAN } \\
\text { India }\end{array}$ & 3,048 & 3,048 & 0 & 3,048 \\
\hline 3 & $\begin{array}{c}\text { Water } \\
\text { Conservati } \\
\text { on Project }\end{array}$ & [iv] & $\begin{array}{l}\text { PAN } \\
\text { India }\end{array}$ & 3,317 & 3,002 & 315 & 3,317 \\
\hline 4 & Ashadan & [iii] & Mumbai & 170 & 170 & - & 170 \\
\hline 5 & $\begin{array}{l}\text { Project } \\
\text { Prabhat }\end{array}$ & {$[\mathrm{x}]$} & $\begin{array}{l}\text { PAN } \\
\text { India }\end{array}$ & 561 & 544 & 17 & 561 \\
\hline 6 & $\begin{array}{c}\text { Domex } \\
\text { Toilet } \\
\text { Academy }\end{array}$ & [i ] & $\begin{array}{l}\text { Andhra } \\
\text { Pradesh }\end{array}$ & 233 & 233 & 0 & 233 \\
\hline 6 & Sanjivini & [i ] & Assam & 75 & 75 & 0 & 75 \\
\hline 7 & Ankur & [iii] & Assam & 28 & 28 & 0 & 28 \\
\hline & TOTAL & & & 11,609 & 11,277 & 332 & 11,609 \\
\hline
\end{tabular}

Source: Compiled from Different Sources

\section{Findings}

- Since the legal provisions of CSR under Companies Act are applicable in HUL, it has to spend at least 2 percent of the average net profits of the company during three immediately preceding financial year against CSR activities.

- It is found that HUL is undertaking 13 CSR activities all over India.

- The most preferred CSR activities were observed to be women empowerment, self employment, health hygiene and environment. 


\section{Conclusion}

Today the concept of CSR has undergone radical change. It has integrated social as well as environmental issues into their missions and decisions. Companies take keen interest in informing about their CSR activities to their stakeholders as well. From the review, we come to know that across the globe, business enterprises have accepted the concept of CSR as an element of success and survival of business along with fulfilling social objectives. However, the challenge for the companies is to determine a strong and innovative CSR strategy which should deliver high performance in ethical, environmental and social areas and meet all the stakeholders' objectives. Movement aimed at encouraging companies to be more aware of the impact of their business on the rest of society, including their own stakeholders and the environment.

\section{References}

Arora, B. \& Puranik. (2004). A Review of Corporate Social Responsibility in India, Development, 47(3), 93-100.

Bansal, H., Parida, V. \& Kumar, P. (2012). Emerging trends of Corporate Social Responsibility in India. KAIM Journal of Management. Vol.4.No.12

Ramana Kumar M. Corporate Social Responsibility (Analysis of Select Indian Private and Public sector companies). In International Journal of Innovative Research in Science \& Engineering ISSN (Online) 2347-3207

Baker, M. (2012). Four emerging trends in Corporate Responsibility.

Chatterjee, D. (2010). Corporate Governance and Corporate Social Responsibility: The case of three Indian companies. International Journal of Innovation, Management and Technology, Vol. 1, No. 5.

Shah, S. \& Bhaskar, S. (2010). Corporate Social Responsibility in an Indian Public Sector Organisation: A case study of Bharat Petroleum Corporation Ltd. Journal of human values. Vol. 16. No. 2. 143-156.

Verma, S. and Chauhan. (2007). Role of Corporate Social Responsibility in Developing Economics. International Marketing \& Society, 8-10 April, 2007, IIMK.

Narang, Jigyasa. Achieving Social Welfare through Corporate Social Responsibility. In Asia Pacific Journal of Research in Business 
Management. Vol.8, issue 7, 2017. ISSN 2229-4104.

PARIPEX - Indian Journal of Research. Volume: 4, Issu: 2, Feb 2015. ISSN -2250-1991. Page 197-200.

http://lexicon.ft.com/Term?term=corporate-social-responsibility--(CSR) https://www.hul.co.in

https://www.worldwidejournals.com/paripex/recent_issues_pdf/2015/Feb ruary/February_2015_1424432558_114.pdf 